\title{
New species of Scolytodes (Coleoptera: Scolytidae) from Costa Rica and Panama
}

\author{
Bjarte H. Jordal 1 \\ 1 University of Bergen, Institute of Zoology, Allégaten 41, N-5007 Bergen, Norway. Fax: +47 55589674. E-mail: \\ Bjarte.Jordal@zmb.uib.no
}

Received 9-IV-1997. Corrected 7-I-1998. Accepted 25-I-1998.

\begin{abstract}
Seven species of Scolytodes (tribe Ctenophorini) are described as new to science: $S$. concavus and $S$. circumsetosus (from Ficus branches, La Selva), S. montanus (Monteverde), S. nudifrons (Las Cruces near San Vito), and $S$. triangulus (fogging sample, La Selva), all from Costa Rica, and $S$. ungulatus (Cerro Punta) and $S$. punctifrons (from Astronium graveolens, Canal Zone), both from Panama. New distributional and host plant data are given for the following species: S. amoenus (Ficus branch, La Selva, and the first record south of Mexico), S. immanis (Cerro de La Muerte), S. impressus (Xylopia branch, Peninsula de Osa), S. ochromae (Ochroma branch, La Selva), S. piceus (fogging sample, La Selva, the first low altitude record), and S. swieteniae (fogging sample, La Selva and Braulio Carrillo, the first exact locality data), all from Costa Rica, and $S$. nanellus (Barro Colorado Island) from Panama.
\end{abstract}

Key words: Scolytodes, taxonomy, Panama, Costa Rica, host-plant, distribution.

The strictly Neotropical genus Scolytodes Ferrari is one of the most speciose genera of Scolytidae. Including the seven species described herein, there are altogether 189 species hitherto described. However, it is expected that many species still remain unknown to science, particularly in the South American fauna. Hence, a great deal of work remains to approach a complete overview of this genus. In this regard, this account intends to contribute to a prospective revision of the genus.

The number of named mainland species of Scolytodes north of the Canal Zone (Panama) is now 78, 45 of which are found in Costa Rica. Rather few species are present north of Costa Rica, most probably due to the climatic change northward or the assumed delay in northward dispersal due to the recent Panamanian land bridge connection (Rich and Rich 1983, but see Jordal 1997, for a discussion on this topic).

Morphology: Scolytodes is readily recognized as a member of the tribe Ctenophorini by the costiform lateral margins of pronotum (Figs 1, 3, 5, 7, 9) and the separated procoxae. It is distinguished from the three other genera of this tribe by the sexual dimorphism, the female frons in most species being impressed, and variously ornamented (Figs 11-20) compared to the absent or reversed dimorphism in the other genera. It is closely related to Gymnochilus 

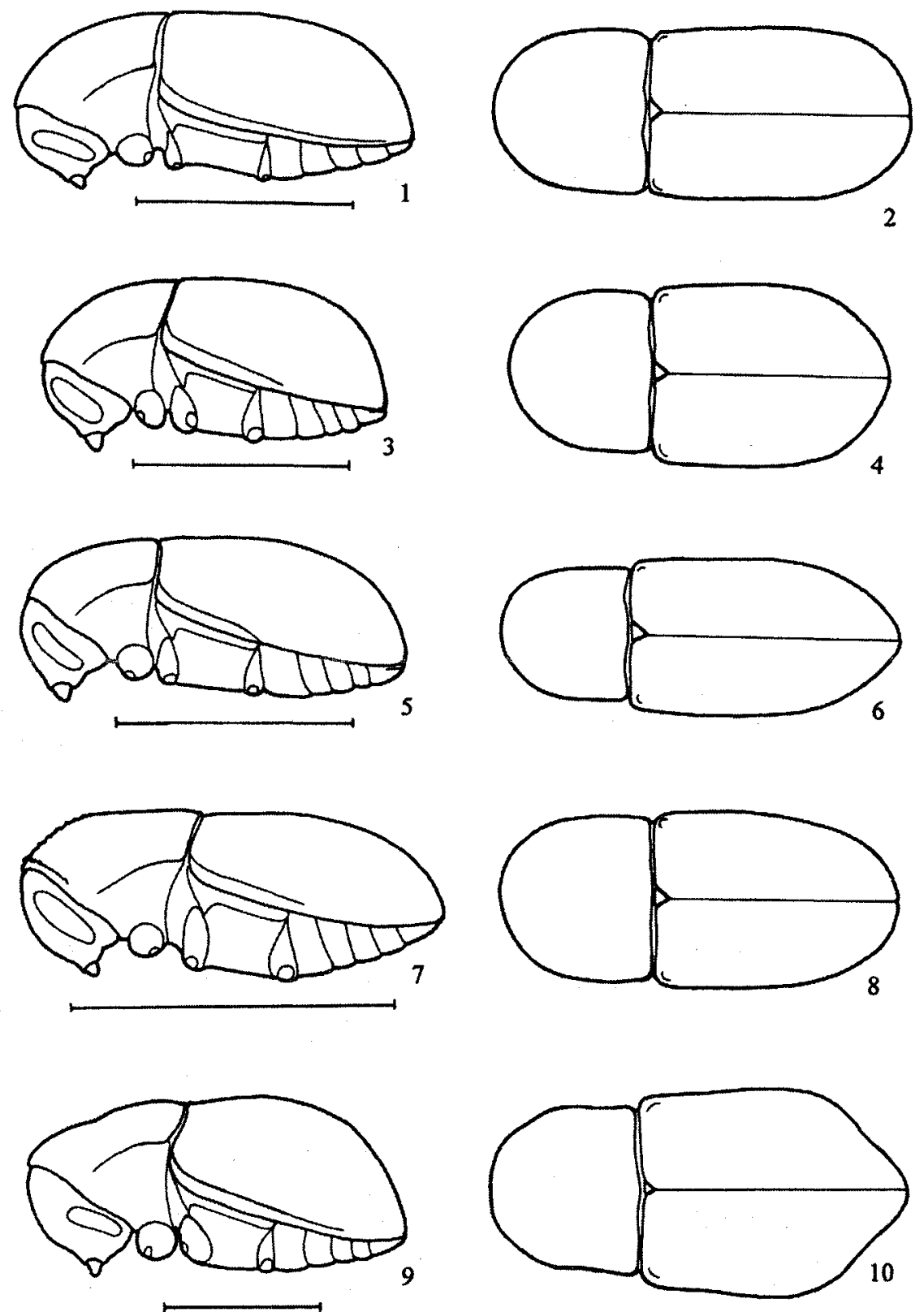

Figs 1-10. Outline sketches of Scolytodes spp.; left, lateral view; right, dorsal view. Scale lines indicate

$1 \mathrm{~mm} .1-2$, S. punctifrons; 3-4, S. concavus; 5-6, S. ungulatus; 7-8, S. circumsetosus; 9-10, $S$. montanus. 

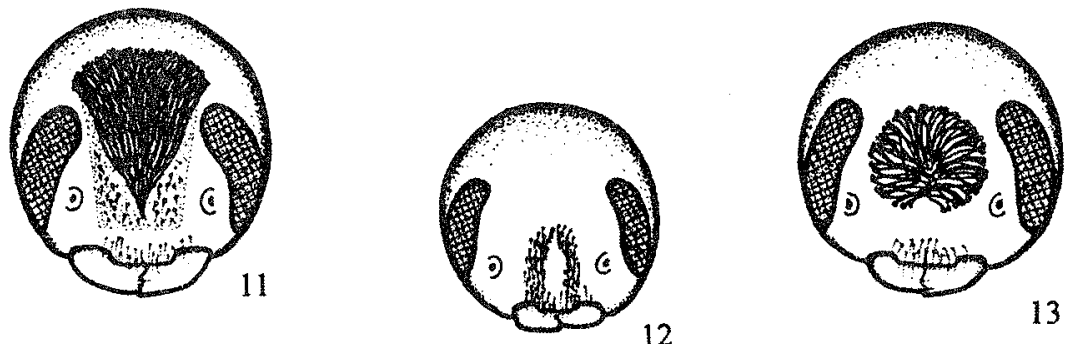

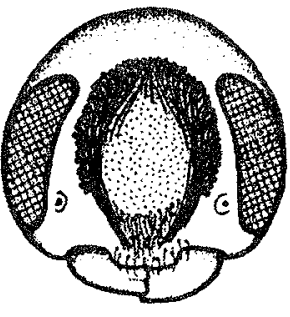

14

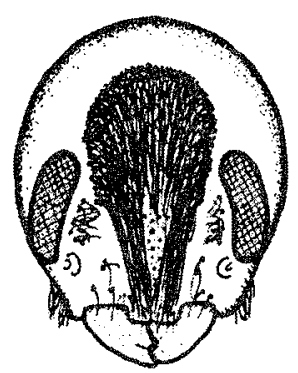

17

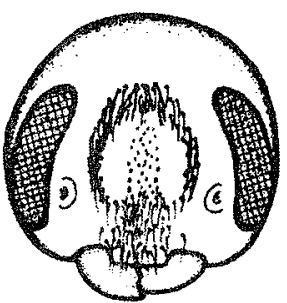

15

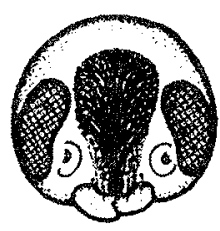

18

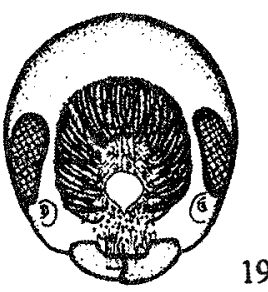

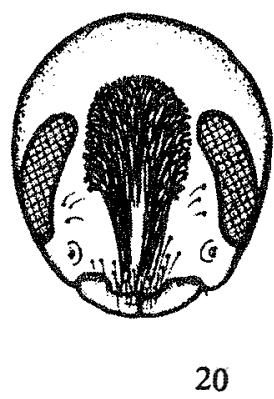

Figs 11-20. Female frons of Scolytodes spp. 11, S. triangulus; 12, S. nudifrons; 13, S. circumsetosus; 14, S. punctifrons; 15, S. ungulatus; 16 , S. concavus; 17, S. imannis; 18, S. nanellus; 19, S. amoenus; 20, S. piceus. 
Reitteri, only reliably distinguished by the antennal funiculus being five or six segmented (Figs 21-25) compared to the seven segmented funiculus in Gymnochilus. It is readily distinguishable from Pycnarthrum Eichhoff and Microborus Blandford by the finely faceted eyes which are not approximate. The most useful species-level characters are variations in female frons (Figs 11-20); the protibial and metatibial teeth positions (Figs 26-32); pronotal crenulations (Fig. 7) and punctation; elytral punctation, vestiture and the length and degree of the acutely raised portion of the tenth interstriae (Figs 1, 3, 5, 7, 9).

Biology: Many species of Scolytodes are only known from one or a few specimens and half of the species are without host-plant records (cf. Wood and Bright 1992), limiting the knowledge about biology of species in this genus. Thus, new records on distribution and host plants are added in the end of this paper. Species with known host associations breed primarily in pith or inner bark of dead angiospermous trees; many collections are from Ficus (Moraceae) and Clusia (Guttiferae) (compiled from Wood and Bright 1992), though even more species (28) are obligate breeders in Cecropia (Cecropiaceae) trees, most of these in dead leafstalks of these trees (Jordal 1997).

\section{MATERIALS AND METHODS}

Collections: locality and host-plant data are cited as written on labels. The ' $F$ ' in e.g. 'FOT' indicates sample by fogging. Holotypes and specimens examined of species described in this paper, are deposited in the following collections:

CNCI -Canadian National Collection of Insects, Arachnids and Nematodes, Ottawa

FMNH -Field Museum of Natural History, Chicago
INBio -Instituto Nacional de Biodiversidad, Heredia, Costa Rica

MIUCR -Museo de Insectos, San José, Costa Rica

SLWC -Stephen L. Wood Collection, Brigham Young University, Provo

Body measurements and terminology: body length was measured from anterior margin of pronotum to apex of elytra in sinistral view; pronotal length and width in dorsal view, with anterior and basal margins in focus concurrently; elytral width in dorsal view; elytral length from ventroanterior angle to apex in sinistral view with body longitudinal axis parallel to optic plane. The prosternum/procoxa ratio was based on measurements of the width of the intercoxal process of prosternum at its posterior margin and the width of one procoxa. Terminology on morphology follows Wood (1982).

Scolytodes concavus n. sp.

(Figs 3, 4, 16, 23, 28)

Holotype female: COSTA RICA, Heredia province: La Selva Biol. Sta., Puerto Viejo, 50 m, 25 Nov. 1993 (L. R. Kirkendall), ex Ficus hispida branch [INBio]. Allotype male: same data as holotype. Paratypes: same data as holotype, 7 \%ᄋ, $30^{\circ} 0^{\circ}$ [INBio], 19, $10^{\circ}$ [SLWC].

Etymology: composed by the Latin prefix con, with, and the Latin cavus, excavated, referring to the concave female frons.

Description female: length $1.47-1.69 \mathrm{~mm}$ $(\mathrm{n}=9), 2.01-2.13(2.08)$ times longer than wide; colour yellowish brown.

Frons strongly, circularly, concavely impressed from upper level of eyes almost to epistoma, margin of impressed area following inner margin of eyes; surface of impressed area rugosely reticulate, dull, punctures not evident; long, golden, subplumose setae arise from vertex and lateral margin of impressed area, 

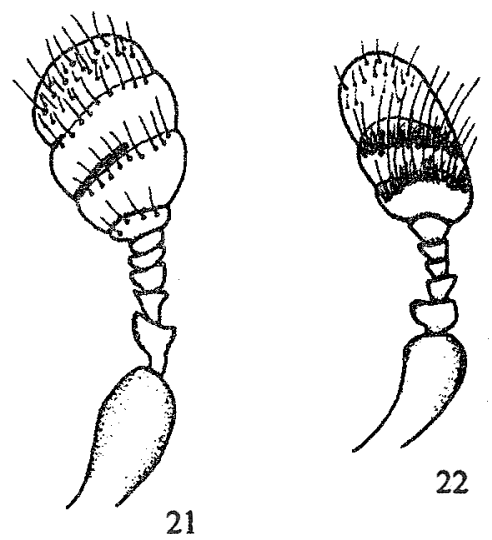

22
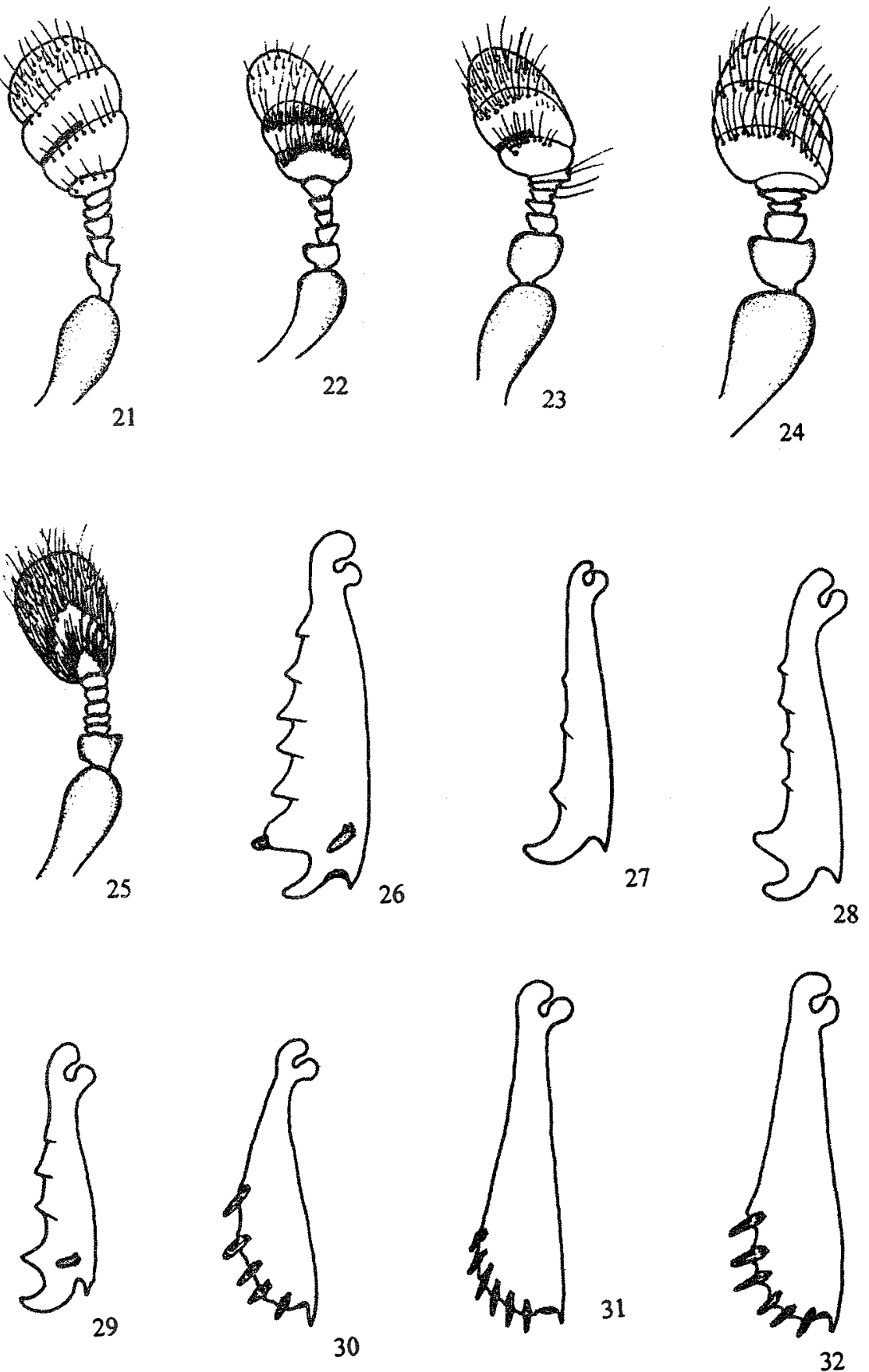

Figs 21-32. Antennae (21-25), protibiae (26-29) and metatibiae (30-32) of Scolytodes spp. 21, 26, 32 S. montanus; $22,31, S$. ungulatus; $23,28, S$. concavus; $24,29,30, S$. circumsetosus; $25,27, S$. triangulus. 
tips of longest setae reaching level of antennal insertion, minute hairlike setae scattered in impressed area, more abundant just above epistoma.

Antennal club small, with two obliquely procurved sutures; first segment subcorneous, with a few hairlike setae. Funiculus six segmented.

Pronotum 0.94-1.01 (0.96) times as long as wide, widest at base, sides subparallel, converging slightly to anterior fourth, rather broadly rounded in front; fine, subgranulate asperities on anterior half; surface reticulate, with fine, shallow punctures on posterior half, spaced by twice diameter of a puncture, slightly smaller punctures present on posterior side of asperities reaching anterior margin; vestiture consisting of two to four long erect setae near anterior margin, two lateral setae slightly displaced mesad and one seta in each basal corner.

Elytra 1.20-1.36 (1.28) times longer than wide, 1.48-1.62 (1.52) longer than pronotum; sides almost straight and parallel on basal two-thirds, rather narrowly rounded behind; striae not impressed, punctures small, shallow, spaced by less than diameter of a puncture; interstriae two times wider than striae, punctures two-third width of strial punctures, mostly uniseriate; interstriae 10 acutely elevated to sternum 3; declivity rather steep, convex; strial and interstrial punctures as on disc. Vestiture consisting of interstrial rows of spatulate bristles, mostly on declivity, bristles as long as distance between rows, slightly closer to one another within a row; minute hairlike setae in rows on striae and interstriae.

Protibiae with lateral teeth 1 and 2 subequally sized, other teeth much smaller. Intercoxal process of prosternum 0.60-0.67 (0.64) times as wide as procoxa. Metatibiae with five socketed lateral teeth on distal third.
Description male: $(n=5)$ similar to female except frons convex, with a weak transverse impression just above epistoma, surface reticulate, dull, a few shallow punctures obscurely present, frontal vestiture confined to sparse short hairlike setae on lower frons and epistoma.

Diagnostic features: The combinations of characters: pronotal asperities on anterior half along with pronotal punctures reaching anterior margin and protibiae without an additional tooth on posterior face along with an interstriae 10 acutely raised to sternum 3 , and further, a very unique female frons, results in a very uncertain classification of this species. It is probably not closely allied to any known species.

\section{Scolytodes circumsetosus $\mathrm{n}$. sp.}

(Figs 7, 8, 13, 24, 29, 30)

Holotype female: COSTA RICA, Heredia province: La Selva biol. sta., Puerto Viejo, 50 m, 14 Sept. 1994 (K. H. Thunes), ex. Ficus branch [INBio]. Allotype male: same data as holotype. Paratypes: same data as holotype, 2 \&Q, 4 ơ $0^{\circ}$ [INBio], 1\%, 10" [SLWC].

Etymology: From Latin circum, around, and Latin setosus, hairy, referring to the circle of setae in the female frons.

Description female: Length 1.39-1.45 $\mathrm{mm}(\mathrm{n}=4), 2.47-2.53$ (2.50) times longer than wide. Colour yellow.

Frons slightly flattened on a circular area occupying median three-fourths, surface of flattened area densely, coarsely punctured, except in a longitudinal, slightly elevated, median fifth area; vestiture made up by a circle of protruding, subplumose setae arising from circular margin of flattened area, a few hairlike setae close to epistoma. 
Antennal club small, two obliquely procurved sutures marked by rows of hairlike setae. Funiculus five segmented.

Pronotum 1.10-1.16 (1.14) times longer than wide, sides parallel, rather broadly rounded in front; asperities on anterior half forming transversely long costae, row closest to anterior margin forming an acutely raised, continuous costa reaching anterolateral angles; surface reticulate, with fine, shallow punctures on posterior half, spaced by diameter of a puncture; vestiture consisting of two erect setae close to anterolateral angles.

Elytra 1.58-1.61 (1.59) times longer than wide, 1.59-1.62 (1.60) times longer than pronotum, sides nearly parallel to declivity, rather narrowly rounded behind; striae not impressed, punctures small, shallow, spaced by diameter of a puncture; interstriae two times wider than striae, punctures obscure, half the width of strial punctures, uniseriate, spaced by three times the width of a puncture; interstriae 10 acutely elevated to sternum 3; declivity convex, gradually curving downwards, strial and interstrial punctures obscure. Vestiture consisting of a few erect setae on disc and posterior sides.

Protibiae with lateral teeth 1 and 2 subequally sized, other lateral teeth much smaller; a small tooth present between lateral tooth 2 and terminal mucro. Intercoxal process of prosternum 0.18-0.27 (0.23) times as wide as procoxa. Metatibiae with six socketed lateral teeth on distal half.

Description male: $(n=6)$ similar to female except length $1.20-1.33 \mathrm{~mm}(\mathrm{n}=6)$, 2.26-2.36 (2.31) times longer than wide. Frons convex, with an abrupt transverse impression just above epistoma, surface reticulate, dull, distinct punctures present from epistoma to upper level of eyes, size of a puncture as large as an ommatidium; frontal vestiture confined to a few hairlike setae close to epistoma. Pronotum 1.06-1.12 (1.08) times longer than wide. Elytra 1.36-1.47 (1.43) times longer than wide, 1.35-1.48 (1.45) times longer than pronotum.

Diagnostic features: It is closely related to $S$. rugicollis (Schedl) and $S$. pannuceus Wood which also have a costiform anterior row of pronotal asperities. It is distinguished from both species by the smaller size (1.2-1.5 $\mathrm{mm}$ vs $1.6-1.9 \mathrm{~mm}$ ) and further from rugicollis by the lack of a procurved callus in the female frons and from pannuceus by the smaller, obscurely impressed elytral punctures.

\section{Scolytodes montanus $\mathrm{n}$. sp.}

(Figs 9, 10, 21, 26, 32)

Holotype male: COSTA RICA, Guanacaste province: Monteverde, $1400 \mathrm{~m}$, 17-18 Aug. 1976 (E. M. Fischer), [INBio].

Etymology: From Latin montanus, belonging to a mountain (mountains), referring to the holotype locality in Cordierra Tilarán.

Description male: length $2.39 \mathrm{~mm}(\mathrm{n}=1)$, 2.00 times longer than wide. Colour dark reddish brown.

Frons convex, except broadly, transversely impressed from epistoma to just above level of antennal insertion; surface shining; coarse, deep punctures present from vertex to epistoma, punctures slightly smaller in impressed area; vestiture consisting of sparse, minute, hairlike setae arising from punctures, setae become more abundant in impressed area and close to epistoma.

Antennal club moderately large, three evident segments marked by two slightly procurved sutures with rows of long, hairlike setae; basal segments 1 and 2 corneous. Funiculus six segmented.

Pronotum 1.02 times longer than wide, sides subparallel, widest at mid-length, narrowly 
rounded in front; asperities absent, surface reticulate, with coarse, deep punctures spaced by one-third the diameter of a puncture; vestiture consisting of eight erect setae, four close to anterior margin, two mesad from anterolateral angles and one in each basal corner.

Elytra 1.33 times longer than wide, 1.58 times longer than pronotum; sides diverging slightly on basal two-thirds, acuminately rounded behind; most striae moderately but distinctly impressed, punctures small, deep, spaced by less than diameter of a puncture; interstriae three times wider than striae, punctures half the width of strial punctures, uniseriate, spaced by five times their diameter; interstriae 10 strongly, acutely elevated to level of metacoxae, continuing as a less elevated line to sternum 5; declivity steep, convex, almost flat on central half, strial and interstrial punctures as on disc, except closer, striae slightly more impressed. Vestiture consisting of interstrial rows of erect bristles, and much shorter strial and interstrial hairlike setae, mostly in rows; vestiture most abundant on declivity.

Protibiae with lateral teeth 1 and 2 subequally sized, five smaller lateral teeth decreasing in size proximally; an additional small tooth present on posterior face close to terminal mucro. Intercoxal process of prosternum as wide as procoxa. Metatibiae with six socketed lateral teeth on distal fourth.

Female unknown.

Diagnostic features: This is an unique species of Ctenophorini, with a clearly exposed socketed lateral tooth 2 on protibiae, with the basal two-thirds embedded in cuticle (Fig. 26). Lateral teeth 1 and 2 appear to be unsocketed in all other Ctenophorini species, but cuticle hides the socketed tooth embedded in each of them. The new finding presented here is consistent with the hypothesis that lateral teeth 1 and 2 of protibiae in Ctenophorini, are of socketed origin (Jordal 1998). The very narrow form of elytral apex
(Fig. 10) is another feature not recognized earlier in this genus or tribe. Despite these aberrancies, this species definitely belongs to the Scolytodes.

\section{Scolytodes nudifrons $\mathrm{n}$. sp.}

(Fig. 12)

Holotype female: COSTA RICA, Puntarenas province: OTS sta., $5 \mathrm{~km}$ SW Finca Las Cruces, $1600 \mathrm{~m}, 21$ March. 1973 (J. Wagner, J. Kethley), Berlese trap, mixed floor litter including leaves and palm fibres [FMNH]. Paratype: same data as holotype 1 \%.

Etymology: From Latin nudi, naked, and frons forehead; referring to the convex, shining, almost glabrous female frons.

Description female: Length 1.13-1.22 $\mathrm{mm}(\mathrm{n}=2), 2.29-2.31$ (2.30) times longer than wide. Colour dark brown.

Frons convex, shining and glabrous from vertex to just above level of antennal insertion, then obliquely impressed on median two-thirds to epistoma, a longitudinal, slightly elevated, obtuse carina present on median one-fifth of impressed area, deep, coarse punctures present along lateral margins of carina, epistoma not elevated; vestiture consisting of a few hairlike setae arising from punctures and epistoma.

Antennal club on posterior face with two oblique sutures indicated by rows of setae, basal half subcorneous; funiculus five segmented.

Pronotum 1.02-1.04 (1.03) times longer than wide, sides weakly arcuate, feebly converging on anterior third, broadly rounded in front; surface shining, subreticulate, strongly reticulate on basal one-third, punctures small, shallow, spaced by three times their diameter; vestiture consisting of two erect, long setae near anterior margin, one slightly mesad of each lateral margin and one in each basal corner. 
Elytra 1.66 times longer than wide, 1.80 times longer than pronotum; sides parallel on basal two-thirds, narrowly rounded behind; striae 1 weakly, others not impressed, punctures fine, shallow, spaced by twice their diameter; interstriae three times wider than striae, shining, punctures not evident; interstriae 10 acutely elevated to level of metacoxae; declivity convex, rather steep, punctures smaller and less impressed than on disc. Vestiture consisting of a total of 25 to 30 erect, long setae on odd-numbered interstriae.

Protibiae with lateral teeth 1 and 2 equally sized, other lateral teeth gradually decreasing in size proximally, a small additional tooth present on posterior face, close to lateral tooth 2. Intercoxal process of prosternum 0.70 times as wide as a procoxa. Metatibiae with six lateral socketed teeth on distal third.

Male unknown.

Diagnostic features: Examination of genitalia revealed spermatheca and that tergite 7 was the terminal tergite; hence, the otherwise male-looking individuals were females. Females of Scolytodes are normally obviously ornamented in the frons, but exceptions in a few species exist (Jordal 1998, this paper). The general outline, the protibiae and elytral ornamentation suggest a close relationship to species in the acares group (sensu Jordal 1998); the convex, nearly glabrous female frons and the placement of a pair of dorsolateral, erect pronotal setae of this species, however, distinguish it from all other species in the group. The absence of males (aedeageal characters) prevents a firm conclusion on the relationship, but it is closer to the acares group than to e.g. S. irazuensis Wood.

\section{Scolytodes punctifrons $\mathrm{n}$. sp.}

(Figs 1, 2, 14)

Holotype female: PANAMA, Panama province: Pr. Nat. Metropolitano, 15 Jan. 1996
(F. Ødegaard), ex Astronium graveolens [INBio]. Paratype: same data as holotype, 12 Jan. 1996, ex: Ficus insipida, 19 [INBIO].

Etymology: From Latin punct, puncture, and frons, forehead; referring to the densely punctured impressed area of the female frons.

Description female: length $1.80-1.83 \mathrm{~mm}$ $(\mathrm{n}=2), 2.38-2.40$ (2.39) times longer than wide; colour yellowish brown.

Frons slightly, concavely impressed from upper level of eyes to epistoma, impressed area narrowing from just above level of antennal insertion to epistoma; surface of impressed area densely marked by small, shallow punctures; vestiture consisting of long, golden, subplumose setae along margin of impressed area, tips of longest setae reaching epistomal lobe, impressed area appears minutely pubescent from dorsal aspect.

Antennal club small, with two slightly procurved sutures marked by rows of hairlike setae; a transverse septum reaching centre at level of suture 1. Funiculus six segmented.

Pronotum 1.05-1.08 (1.06) times longer than wide, widest at base, sides converging slightly to anterior fourth, rather narrowly rounded in front; coarse, subcontiguous, transverse asperities on anterior half, first row forming an unbroken costa close to anterior margin; surface subreticulate, subshining, with moderately coarse, deep punctures on posterior half only, spaced by diameter of a puncture; vestiture consisting of six erect, long setae, four along anterior margin and one in each basal corner.

Elytra 1.48-1.51 (1.50) times longer than wide, 1.46-1.47 (1.46) longer than pronotum; sides parallel on basal three-fourths, broadly rounded behind; striae not impressed, punctures rather deep, spaced by diameter of a puncture; interstriae almost twice as wide as striae, shining, punctures two-third the size of 
strial punctures, uniseriate; interstriae 10 acutely elevated to sternum 6; declivity steep, convex, strial and interstrial punctures slightly smaller than on disc, striae 1 weakly impressed. Vestiture consisting of four erect setae on disc, two on each interstriae 3.

Protibiae with lateral teeth 1 and 2 subequally sized, other lateral teeth much smaller. Metatibiae with five socketed lateral teeth on distal third.

\section{Male unknown.}

Diagnostic features: It is distinguished from the closely related S. schwarzi (Hopkins) (see fig. 142 p. 496 in Wood 1982) by the larger size $(1.8 \mathrm{~mm}$ vs $1.3-1.6 \mathrm{~mm})$, by the asperities being confined to anterior half, and by the female frons being punctured throughout the impressed area.

\section{Scolytodes triangulus $\mathrm{n}$. sp.}

(Figs 11, 25, 27)

Holotype female: COSTA RICA, Heredia province: La Selva biol. sta., Puerto Viejo, 50 m, 5 March 1993 (H. A. Hespenheide), FOT 5/16 Carapa guianensis [INBio]. Allotype: same data as holotype, FOT 02/13. Paratype: Costa Rica, Puntarenas: Osa Peninsula, $2.5 \mathrm{mi}$. SW Rincon, 7 March 1988 (H. Hespenheide), air sweep, $1_{\text {_ }}$ [INBio].

Etymology: From Latin tri, three, and angulus, having a corner, referring to the triangular shaped tuft of setae in the female frons.

Description female: Length 1.40-1.50 $\mathrm{mm}(\mathrm{n}=2), 2.05-2.15(2.10)$ times longer than wide; mature colour brown.

Frons slightly impressed from above upper level of eyes to epistoma, lateral margins of impressed area slightly raised, subparallel, slightly diverging towards upper level of eyes; surface of impressed area densely punctured at median two-thirds, minute setae arising from most punctures; vestiture consisting of a triangular tuft of long, golden, subplumose setae, broadly arising at vertex, then gradually converging toward the tip at level of antennal insertion.

Antennal club with two strongly, acuminately procurved sutures marked by rows of hairlike setae, terminal segment setose. Funiculus six segmented.

Pronotum 1.02-1.04 (1.03) times longer than wide, widest at base, sides weakly arcuate, converging slightly to anterior fourth, then broadly rounded in front; anterior third declivuous, asperities rather coarse, finer asperities continue to basal third; surface reticulate, dull, a few shallow punctures present on posterior half except small, shining granules present in median basal area; vestiture consisting of four short, erect setae along anterior margin.

Elytra 1.19-1.23 (1.21) times longer than wide, 1.21-1.23 (1.22) longer than pronotum; sides parallel on less than basal two-thirds, rather narrowly rounded behind; striae 1 slightly, others not impressed, punctures shallow, small, spaced by half a diameter of a puncture; interstriae two to three times wider than striae, shining, punctures obscure, twothird the size of strial punctures, spaced by almost twice their diameter, mostly uniseriate; interstriae 10 acutely raised almost to apex; declivity moderately steep, convex, all punctures obscure. Vestiture consisting of sparse spatulate bristles on odd-numbered interstriae, mostly on declivity.

Protibiae with a strong lateral tooth 1 extending beyond tooth 2 , other lateral teeth obscurely indicated. Intercoxal process of prosternum 0.30-0.40 times as wide as a procoxa. Metatibiae with six socketed lateral teeth on distal third. 
Description male: $(n=1)$ similar to female except frons convex, only slightly, transversely impressed just above epistoma; frontal vestiture consisting of sparse, minute, hairlike setae close to epistoma.

Diagnostic features: This species is closely related to $S$. cedrelae Wood from which it can be distiguished by the lack of a median longitudinal carinae from epistoma to level of antennal insertion. Pronotal and elytral sculpturing appear identical.

\section{Scolytodes ungulatus $\mathrm{n} . \mathrm{sp}$.}

(Figs 5, 6, 15, 22, 31)

Holotype female: PANAMA, Chiriquí province: 2-3 km E Cerro Punta, 2000-2200 m, 23 May 1977 (H. \& A. Howden) [CNCI].

Etymology: From Latin ungula, hoof or claw, referring to the hoof formed pair of calli in the female frons.

Description female: Length $1.62 \mathrm{~mm}$, 2.46 times longer than wide $(n=1)$. Colour black.

Frons rather deeply, narrowly impressed from upper level of eyes to epistoma, a pair of shining, hoof-formed calli close to lateral margins on longitudinal central half; surface shining, punctures in impressed area coarse, deep, close; vestiture consisting of scant, hairlike setae along margin of impressed area and on epistoma, minute setae present between calli.

Antennal club with two slightly procurved sutures marked by rows of hairlike setae. Funiculus five segmented.

Pronotum 1.04 times longer than wide, sides subparallel, weakly arcuate, widest at mid-length, rather broadly rounded in front; asperities obscurely present on anterior fourth; surface reticulate, with moderately coarse, deep punctures spaced by twice their diameter, slightly shallower punctures reaching anterior margin; vestiture consisting of six erect setae, four along anterior margin and one in each basal corner, minute, obscure setae arise from punctures.

Elytra 1.63 times longer than wide, 1.84 times longer than pronotum; sides straight and parallel on basal two-thirds, narrowly rounded behind; striae not impressed, pairs of longitudinally, subconfluent, small punctures, shallow but sharply defined, pairs of punctures spaced by length of a pair; interstriae four times wider than striae, shining, punctures as in striae but single, uniseriate, spaced by four times their diameter; interstriae 10 acutely elevated to level of metacoxae; declivity moderately steep, convex, punctures as on disc. Vestiture consisting of rows of erect, long setae on interstriae 3 and 7 , setae spaced within rows by little more than length of setae; minute, obscure, hairlike setae in strial and interstrial rows.

Protibiae with lateral teeth 1 and 2 equally sized, four smaller lateral teeth decreasing in size proximally; an additional small tooth present on posterior face slightly mesad of a line between lateral teeth 1 and 2 . Intercoxal process of prosternum 0.25 times as wide as procoxa. Metatibiae with six socketed lateral teeth on distal fourth.

Male unknown.

Diagnostic features: This species is closely related to $S$. irazuensis, from which it is distinguished by the narrowly and less impressed female frons, and the lack of erect setae on interstriae 1 and 5 .

\section{DISTRIBUTION AND HOST PLANT}

Due to the paucity of knowledge about most species' biology and distribution, some new records on host tree and distribution are given below. 
1. Scolytodes amoenus Wood (Fig. 19): Costa Rica, Heredia: La Selva Biol. Sta, Puerto Viejo, 50 m, 25-26 Nov. 1993 (L. R. Kirkendall), ex: Ficus insipida branch $20^{\circ} 0^{\circ}, 1 \%$ [MIUCR]. This is the first record of this species in Central America (Costa Rica). It has been collected several times from dead Ficus branches in Mexico (Wood 1982, Equihua-Martinez and Atkinson 1986).

2. Scolytodes immanis Wood (Fig. 17): Costa Rica, San José: Hwy. \#2 at Cerro de la Muerte, 3200 m, 13 Apr. 1985 (H. Goulet - L. Masner) 1 [ [CNCI]. This is the third specimen collected, from the same mountain area as the two types were collected (Wood 1982), confirming the Costa Rican high altitude distribution of this species.

3. Scolytodes impressus Wood: Costa Rica, Puntarenas: Boscosa, 6 km SW Rincon, Pen. Osa, 100 m, 23 Apr. 1994 (L. Kirkendall and D. Quintero), ex: under bark of Xylopia sp. 13 ơ? [MIUCR]. This second record is the first known host tree record (fam. Annonaceae) of this species and the first record from western Costa Rica. The type series was collected from the Atlantic slope of Costa Rica. It should be noted that females of this species are morphologically similar to males and have a convex, almost glabrous frons. The type series by Wood (1982) includes females as well as males, the latter was the only sex described. Sexes can only be distinguished by the terminal tergites or genitalia as in the close relative $S$. pacificus Jordal (see Jordal 1998).

4. Scolytodes nanellus Wood (Fig. 18): Panama, Canal Zone: Barro Colorado Island, 15 Jan. 1959 (H. Dybas) 19 [FMNH]. This is the fifth specimen collected of this species, close to the type locality on BCI. Host tree remains unknown.
5. Scolytodes ochromae Wood: Costa Rica, Heredia: La Selva Biol. Sta, Puerto Viejo, 50 m, 25-26 Nov. 1993 (L. R. Kirkendall), ex: Ochroma velutina branch 19 [MIUCR]. This is the second record of this species and the first one from the Atlantic lowland of Costa Rica. Both collections are from Ochroma. It is formerly collected from the Pacific lowlands of Costa Rica (Wood 1982).

6. Scolytodes piceus (Blackman) (Fig. 20): Costa Rica, Heredia: La Selva Biol. Sta, Puerto Viejo, $50 \mathrm{~m}$, fogging: Virola koschnyi (7 Enero, 1994, FVK/17/02) (INBio-OET) 19 [INBio]; fogging: Vitex cooperi (5 Enero, 1994, FOT/16/12) (INBio-OET) 10' [INBio]. This is the first lowland record of this species. Previous collections are from Tapanti $(1300 \mathrm{~m})$, Costa Rica, and Chiriquì (1400 m), Panama (twice). The lowland specimens differ from the highland populations (Fig. 20) by being smaller $(1.6 \mathrm{~mm}$ vs $2.0 \mathrm{~mm})$ and by having slightly larger, closer eyes. The size difference can probably be explained by the positive correlation between altitude and body size which has been demonstrated for many other Costa Rican species of this genus (Jordal 1998); the slightly larger eyes might be an allometric artifact of being smaller. The aedeagus of this male and of males from Chiriquí, Panama, are identical (rather similar to the aedeagus of $S$. punctifer Wood, see figs 10f-g in Jordal 1998); consequently the lowland population is most probably of $S$. piceus. More material, however, might provide evidence for a new species.

7. Scolytodes swieteniae (Blackman): Costa Rica, Heredia: La Selva Biol. Sta, Puerto Viejo, 50 m, May 1993, fogging: Virola koschnyi (INBio-OET), 10" [INBio]; Braulio Carrillo N.P., 500 m, 10 Apr. 1985 (H. Goulet - L. Masner) $10^{7}$ [CNCI]. This species is only recorded from intercepted logs from Costa Rica; the exact type 
locality is unknown (Blackman 1943, Wood 1982). The records of specimens six and seven presented here, suggest that the distribution might be confined to the Atlantic slope and lowland of Costa Rica.

8. Scolytodes unipunctatus (Blandford): Kirkendall and Wood (in press) recorded this species for the first time since the Guatemalan type series by Blandford (1897) were collected, and was then the first record for Costa Rica (San José: Zurqui de moravia, $1300 \mathrm{~m}$ ). Additional specimens were collected from the same locality by Kirkendall (pers. comm.) in 1997, from Cecropia trunks. This is the 29th species of Scolytodes collected from this host plant.

\section{ACKNOWLEDGMENTS}

This work had not been obtainable without the help provided by Stephen L. Wood who verified some of my identifications and compared most holotypes which are designated here, with holotypes of related species in his collection [SLWC]. I thank the curators at CNCI, Donald Bright, and FMNH, Philip Parille, for exellent and rapid responses to my requests of scolytids. Thanks are due to Henry A. Hespenheide, Frode Ødegaard, Karl H. Thunes and Lawrence R. Kirkendall for collecting and/or providing the additional specimens which are treated in this paper. Kirkendall also made comments on the manuscript.

\section{REFERENCES}

Blackman, M. W. 1943. New species of American scolytoid beetles, mostly Neotropical. Proc. U.S. Nat. Mus. 94: 371-399.

Blandford, W. F. H. 1897. Scolytidae. In Biologia CentraliAmericana, Coleoptera 4: 145-184.

Equihua-Martinez, A. \& T. H. Atkinson. 1986. Annotated checklist of bark and ambrosia beetles (Coleoptera, Scolytidae and Platypodidae) associated with a tropical decidious forest at Chamela, Jalisco, Mexico. Florida Ent. 69: 619-628.

Jordal, B. H. 1998. A review of Scolytodes Ferrari (Coleoptera: Scolytidae) associated with Cecropia (Cecropiaceae) in the northern Neotropics. J. Nat. Hist. 32:81-84

Kirkendall, L. R. \& S. L. Wood. (in press). Cloud forest bark and ambrosia beetles (Scolytidae, Platypodidae) of Costa Rica. In N. Nadkarni (ed.). The natural history, ecology, and conservation of Monteverde, Costa Rica. Oxford University, Oxford.

Rich, P. V. \& T. H. Rich. 1983. The Central American dispersal route: biotic history and paleogeographỳ, $\mathrm{p}$. 12-34. In D. Janzen (ed.). Costa Rican natural history. University of Chicago, Chicago.

Wood, S. L. 1982. The bark and ambrosia beetles of North and Central America (Coleoptera: Scolytidae). Great Basin Nat. Mem. 6: 1-1359.

Wood, S. L. \& D. Bright. 1992. A catalog of Scolytidae and Platypodidae (Coleoptera). Part 2: Taxonomic index. Great Basin Nat. Mem. 13: 1-1553. 